\title{
PENINGKATAN KUALITAS CITRA STEGO PADA ADAPTIVE PIXEL BLOCK GROUPING REDUCTION ERROR EXPANSION DENGAN VARIASI MODEL SCANNING PADA PEMBENTUKAN KELOMPOK PIKSEL
}

\author{
Hendro E. Prabowo ${ }^{1}$, Tohari Ahmad ${ }^{2}$ \\ ${ }^{1,2}$ Departement Informatika, Institut Teknologi Sepuluh Nopember, Surabaya \\ Email : ${ }^{1}$ hendro16@mhs.if.its.ac.id, ${ }^{2}$ tohari@if.its.ac.id
}

(Naskah masuk: 25 Januari 2018, diterima untuk diterbitkan: 18 Mei 2018)

\begin{abstract}
Abstrak
Kebutuhan komunikasi yang terus bertambah dan ditandai dengan meningkatnya jumlah IP traffic dari 744 EB menjadi 1.164 EB menjadikan keamanan sebagai salah satu kebutuhan utama dalam menjaga kerahasiaan data. Adaptive Pixel Block Grouping Reduction Error Expansion (APBG-REE) sebagai salah satu metode data hiding dapat diterapkan untuk memenuhi kebutuhan tersebut. Metode ini akan membagi citra carrier menjadi blok-blok dan membentuknya menjadi kelompok-kelompok piksel. Hasil dari proses ini akan dimanfaatkan untuk menyembunyikan data rahasia. Namun, metode ini memiliki kekurangan, yaitu belum diketahuinya metode scanning terbaik dalam pembentukan kelompok piksel untuk menciptakan citra stego dengan kualitas tinggi. Untuk mengatasi masalah ini, kami mengusulkan 4 mode (cara) scanning berdasarkan arah scanning tersebut. Mode scanning tersebut memberikan hasil yang berbeda-beda untuk masing-masing citra stego yang diujikan. Namun berdasarkan hasil uji coba, setiap mode scanning mampu menjaga kualitas citra stego diatas 57,5 dB. Hasil ini akan meningkat seiring dengan berkurangnya jumlah shifted pixel yang terbentuk.
\end{abstract}

Kata kunci: Penyembunyian data; Keamanan data; Keamanan informasi; Pengelompokan nilai piksel.

\section{STEGO IMAGE QUALITY ENHANCEMENT ON ADAPTIVE PIXEL BLOCK GROUPING REDUCTION ERROR EXPANSION BY VARYING BLOCK PIXEL GROUPING SCANNING MODELS}

\begin{abstract}
The need of communication has increased continously which is represented by the rise of number of IP traffic, from 744 EB to 1.164 EB. This has made data security one of the main requirements in terms of securing secret data. Adaptive Pixel Block Grouping Reduction Error Expansion (APBG-REE) as one of data hiding methods can be implemented to meet that requirement. It divides the carrier image into blocks which are then used as pixel groups. The result of this process is to be a space for secret data. However, this method has a problem in the scanning when creating pixel groups to generate a high quality stego image. To handle this problem, we propose four scanning models base on its direction. This means that the scanning can be done row-by-row or column-by-column. Base on the experiment, we find that those modes deliver various results and each of them is able to maintain the stego quality of more than $57,5 \mathrm{~dB}$. This result increases along with the decreasing the number of shifted pixels.
\end{abstract}

Keywords: Data hiding; Data security; Information security; Pixel value grouping.

\section{PENDAHULUAN}

Teknologi penyimpanan awan (cloud storage) yang merupakan hasil dari perkembangan teknologi informasi dan komunikasi memberikan efek peningkatan jumlah komunikasi yang terjadi antara pengguna (user) dan data center. Hal ini ditunjukkan dengan meningkatkanya IP traffic dari 744 exabyte (EB) pada tahun 2015 menjadi 1.164
EB pada tahun 2017 (CISCO, 2016). Adanya kondisi ini membuat keamanan data menjadi salah satu kebutuhan dasar dalam proses komunikasi tersebut, baik antar-user maupun user dengan data center. Terdapat beberapa cara yang dapat digunakan untuk memenuhi kebutuhan tersebut, diantaranya adalah penyandian data (data encryption) dan penyembunyian data (data hiding). Perbedaan dari kedua metode tersebut adalah bentuk akhir dari data yang diamankan. Dalam data 
encryption, data disandikan secara acak menggunakan algoritma kriptografi. Sedangkan pada data hiding, data akan disisipkan dalam media digital (citra, audio, video, dan teks) sehingga data tersebut menjadi tidak terlihat (Holil \& Ahmad, 2015; Marwan, dkk., 2016; Kurniawan \& Ahmad, 2016). Kelebihan ini menjadikan metode data hiding terus dikembangkan. Namun dalam pengembangan tersebut juga perlu diperhatikan agar media yang disisipi data (carrier) tidak berubah terlalu signifikan dengan menjaga kapasitas penyimpanan tetap besar (Wu, 2002; Arya, dkk., 2016; Andra, dkk., 2017)

Salah satu metode yang terus dikembangkan hingga saat ini adalah histogram shifting $(H S)$ dan difference expansion (DE). HS pertama kali diusulkan oleh $\mathrm{Ni}$ dkk. dan menggunakan titik tertinggi dan terendah pada histogram sebagai tempat untuk menyisipkan data/pesan (Ni, dkk., 2006). Kekurangan dari metode ini adalah kapasitas penyisipan terbatas pada jumlah titik tertinggi dan terendah pada histogram. Berbeda dengan HS, DE memanfaatkan selisih dari nilai piksel yang bertetangga untuk menyisipkan pesan (Tian, 2003; Holil \& Ahmad, 2014). Nilai ini yang mempengaruhi besar perubahan nilai piksel setelah proses penyisipan dan berakibat pada kualitas dari citra stego, citra yang dihasil dari proses penyisipan data. Semakin besar perubahan nilai piksel yang terjadi, maka semakin menurun pula kualitas citra stego tersebut. Perihal kapasitas, DE hanya mampu menyisipkan data rata-rata sebanyak 0.5 bit per pixel (bpp). Kekurangan ini yang kemudian dikembangkan lebih lanjut dalam penelitian lain seperti transform generalization (Gui, dkk., 2012; Peng, dkk., 2012), location map reduction (Liu, dkk., 2012; Chen, dkk., 2016), prediction error expansion (PEE) (Ou, dkk., 2013; Ioan-Catalin \& Coltuc, 2014; Ou, dkk., 2016), dan pixel value ordering (PVO) (Li, dkk., 2013; Peng, dkk., 2014; Weng, dkk., 2016) untuk mendapatkan hasil yang lebih baik.

PVO dikembangkan oleh $\mathrm{Li}$ dengan menerapkan konsep pengurutan (sorting) sebagai pengembangan dari PEE (Li, dkk., 2013). Konsep ini digunakan untuk memprediksi perubahan nilai piksel yang akan terjadi setelah proses penyisipan berlangsung. Dalam metode ini, data atau pesan disisipkan ke dalam nilai prediktor tersebut. Hasil yang didapatkan adalah metode PVO memberikan kualitas citra stego yang lebih baik yaitu rata-rata 2$3 \mathrm{~dB}$. Namun PVO hanya menyisipkan data pada hasil prediksi bernilai 1, sedangkan piksel dengan hasil prediktor bernilai lebih dari 1 akan digeser sebesar 1 poin dan piksel tersebut disebut sebagai shifted pixel. Hal ini yang menjadi kekurangan dari PVO karena kapasitas yang dihasilkan kurang maksimal.

Kekurangan tersebut kemudian dikembangkan lebih lanjut oleh Peng dkk. dengan mengusulkan proses prediksi yang berbeda yaitu dengan memanfaatkan algoritma min dan max pada masingmasing blok piksel dari PVO (Peng, dkk., 2014). Usulan dari Peng dkk menjadikan data dapat disisipkan pada hasil prediktor bernilai 0 dan 1 sedangkan yang lainnya akan digeser sebesar 1 poin. Hal ini memberikan efek positif dalam PVO yaitu dapat meningkatkan kapasitas penyisipan sekitar dua kali lebih pesar dibandingkan metode dari Li dkk.

Pengembangan lain dari PVO juga dilakukan oleh Weng dkk. yang menerapkan konsep dinamis dalam memilih piksel-piksel yang akan digunakan untuk penyisipan data dari sebuah blok (Weng, dkk., 2016). Hasil dari penerapan tersebut, Weng dapat membedakan blok-blok untuk penyisipan data berdasarkan korelasi dengan piksel-piksel disekitarnya. Blok ini dibedakan menjadi 3 jenis, yaitu high correlation, moderate correlation dan low correlation. Setiap jenis blok memiliki kemampuan yang berbeda dalam hal kapasitas penyisipan data. High correlation dapat disisipi sebanyak 6 bit data per blok. Sedangkan moderate dan low correlation, masing-masing dapat disisipi data sebesar 4 bit data dan 2 bit data per blok.

Tetapi beberapa pengembangan tersebut belum maksimal dalam memanfaatkan blok untuk penyisipan. Kondisi ini digunakan oleh Prabowo untuk mengembangkan konsep pengelompokan piksel dalam blok yang bernilai mirip (Prabowo, 2018). Dengan menggunakan konsep ini, mereka dapat meningkatkan kapasitas penyisipan menjadi rata-rata 6-7 kali lebih besar untuk kelompok gambar grayscale dan 16-18 kali lebih besar untuk kelompok gambar medical image dibandingkan dengan metode usulan Peng. Disisi lain, metode dari Prabowo juga menurunkan jumlah shifted pixel yang berbengaruh pada kualitas citra stego sehingga menjadi lebih baik. Namun masih terdapat permasalahan dalam hal proses scanning pada penelitian tersebut yang hanya memberikan satu konsep proses scanning seperti yang terlihat pada Gambar 1. Oleh karena itu, proses scanning ini masih perlu diketahui lebih lanjut efeknya terhadap kualitas citra stego. 


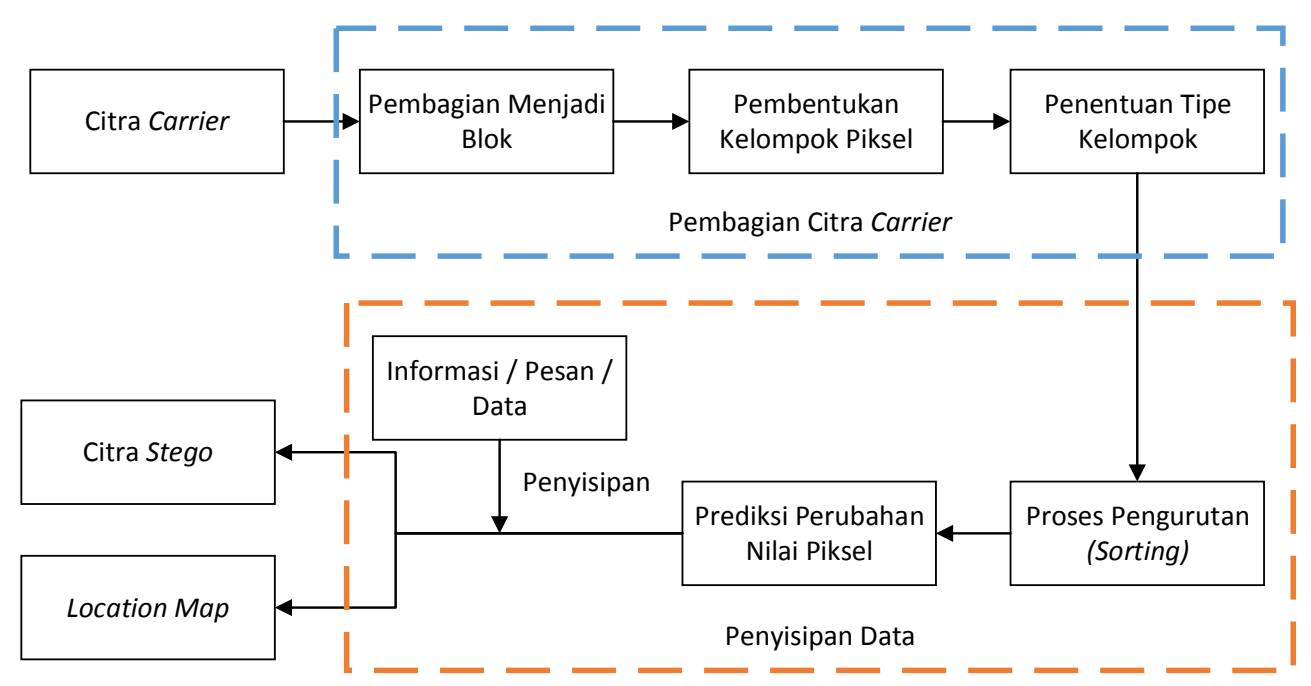

Gambar 2. Proses penyisipan data pada (Prabowo, 2018)

Pada penelitian ini, kami menerapakan beberapa konsep scanning yang berbeda. Perbedaan ini dilakukan berdasarkan scanning pada kolom dahulu atau pada baris dahulu. Selain itu juga dilakukan proses scanning dengan bentuk spiral. Hal ini dilakukan untuk mendapatkan proses scanning yang dapat menghasilkan kualitas citra stego terbaik.

Struktur dari penelitian ini adalah sebagai berikut. Bab II menjelaskan metode referensi yang digunakan. Usulan konsep scanning disajikan pada Bab III, serta hasil dari penerapan konsep yang diusulkan dan pembahasannya dapat dijelaskan pada Bab IV. Terakhir, penelitian ini disimpulkan hasilnya pada Bab V.

\section{METODE REFERENSI}

Pada bab ini, kami akan menjelaskan secara singkat metode peningkatan algoritma pixel value ordering $(P V O)$ oleh Peng, adaptive pixel block grouping dan reduction error expansion yang merupakan metode usulan dari (Prabowo, 2018). Metode referensi ini merupakan dasar dari pengembangan konsep scanning pada data hiding yang kami usulkan.

\subsection{Pixel Value Ordering}

Metode ini diusulkan untuk memperbaiki $P V O$ yang diusulkan oleh $\mathrm{Li}$ yang hanya dapat menyisipkan data pada prediktor $d=1(\mathrm{Li}$, dkk., 2013). Dari masalah ini, mereka mengusulkan konsep penghitungan nilai prediktor agar penyisipan data dapat dilakukan pada $d=0$. Usulan ini dapat dilihat pada persamaan (1) dan nilai piksel untuk citra stego didapatkan menggunakan persamaan (2)(3).

$$
d_{\max }=P_{u}-P_{v}
$$

$$
\begin{aligned}
& d_{\text {max }}^{\prime}= \begin{cases}d_{\max }+b, & \text { jika } d_{\text {max }}=1 \\
d_{\max }+1, & \text { jika } d_{\max }>1 \\
d_{\max }-b, & \text { jika } d_{\max }=0 \\
d_{\max }-1, & \text { jika } d_{\max }<0\end{cases} \\
& P_{\sigma(n)}^{\prime}=P_{\sigma(n-1)}+\left|d_{\text {max }}^{\prime}\right| \\
& = \begin{cases}P_{\sigma(n)}+b, & \text { jika } d_{\max }=1 \\
P_{\sigma(n)}+1, & \text { jika } d_{\text {max }}>1 \\
P_{\sigma(n)}-b, & \text { jika } d_{\max }=0 \\
P_{\sigma(n)}-1, & \text { jika } d_{\max }<0\end{cases}
\end{aligned}
$$

Di sini, $P_{u}$ adalah piksel indeks terkecil, $P_{v}$ adalah piksel indeks terbesar, $d_{\max }$ adalah nilai prediktor pada piksel maksimum, $b$ adalah pesan yang disisipkan, $P_{\sigma(n)}$ adalah piksel dengan nilai maksimum pada citra carrier, dan $P_{\sigma(n-1)}$ adalah piksel prediktor. Sedangkan untuk proses ekstraksi, Peng menggunakan cara yang berbeda, yaitu sebagai berikut (Peng, dkk., 2014):

- Jika $d_{\text {max }}^{\prime}>0$, maka kemungkinan data yang disisipkan adalah :

- Jika $d_{\text {max }}^{\prime} \in\{1,2\}$, maka data yang disisipkan adalah $b=d_{\text {max }}^{\prime}-1$ dan piksel asli bernilai $P_{\sigma(n)}=P^{\prime}{ }_{u}-b$;

- Jika $d_{\text {max }}^{\prime}>2$, maka tidak ada data yang disisipkan, dan nilai piksel asli adalah $P_{\sigma(n)}=P^{\prime}{ }_{u}-1$;

Jika $d_{\text {max }}^{\prime} \leq 0$, maka kemungkinan data yang disisipkan adalah :

- Jika $d_{\text {max }}^{\prime} \in\{0,-1\}$, maka data yang disisipkan adalah $b=-d_{\text {max }}^{\prime}$ dan piksel asli bernilai $P_{\sigma(n)}=P^{\prime}{ }_{v}-b$;

- Jika $d_{\text {max }}^{\prime}<-1$, maka tidak ada data yang disisipkan, dan nilai piksel asli adalah $P_{\sigma(n)}=P_{v}^{\prime}-1$; 
Pada konsep tersebut, penyisipan dan ekstraksi data juga dapat diterapkan pada piksel minimum. Hal ini memberikan efek positif dengan meningkatnya kapasitas penyisipan data dari metode PVO.

\subsection{Adaptive Pixel Block Grouping Reduction Error Expansion (APBG-REE)}

Metode ini diusulkan oleh (Prabowo, 2018) dan secara garis besar, proses data hiding pada metode ini dapat dilihat pada Gambar 2 yang menunjukkan bahwa proses ini dibedakan menjadi dua. Pertama pembagian citra yang akan disisipi data (carrier) menjadi beberapa kelompok piksel dan kedua proses penyisipan data. Metode adaptive pixel block grouping (APBG) terletak pada proses pembagian citra sedangkan reduction error expansion (REE) terdapat pada bagian penyisipan data.

Setelah dilakukan pembagian citra carrier menjadi blok-blok, maka diterapkan metode APBG untuk membentuk kelompok piksel. Proses ini akan menghitung selisih nilai piksel yang digunakan sebagai pixel group head $\left(P G_{h}\right)$ dengan pikselpiksel lainnya $\left(P_{k}\right)$ dalam satu blok menggunakan persamaan (4). Arah proses scanning untuk pembandingan piksel menggunakan konsep seperti terlihat pada Gambar 1 dan piksel akan dikelompokkan dalam satu kelompok jika memenuhi persamaan (5).

$$
\begin{aligned}
& \text { diff }=\left|P_{k+i}-P G_{h}\right| \\
& \text { diff } \leq E L
\end{aligned}
$$

Dalam hal ini, diff adalah nilai selisih piksel, $i$ adalah $1,2,3, \ldots, n$ yang melambangkan jumlah

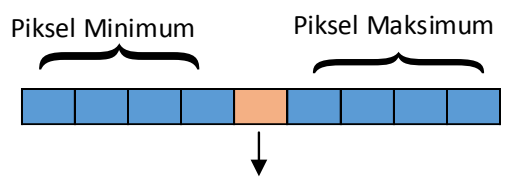

Piksel Prediktor

(a)

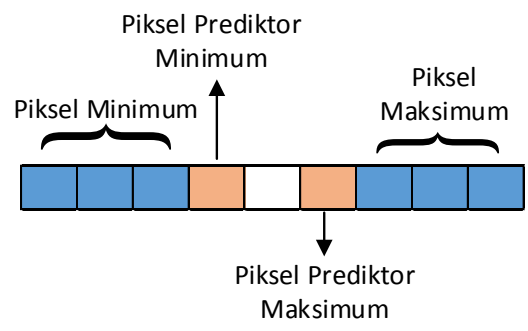

(c) piksel dalam blok dan $E L$ adalah embedding level/threshold sebagai nilai pembatas dalam pengelompokan piksel. Jika persamaan tersebut tidak terpenuhi, maka piksel yang bersangkutan tidak dapat dikelompokkan dengan $P G_{h}$ dan disebut sebagai non-pixel grouping $(N P G)$. Piksel ini kemudian digunakan sebagai $P G_{h}$ baru serta proses pengelompokan dimulai kembali. Piksel yang terakhir bergabung dalam kelompok dinamakan sebagai pixel group tail $\left(P G_{t}\right)$. Sedangkan piksel yang terletak antara $P G_{h}$ dan $P G_{t}$ disebut sebagai pixel group body $\left(P G_{b}\right)$. Pada APBG, satu kelompok minimal terdiri dari 2 piksel yang salah satunya merupakan $P G_{h}$.

Kelompok piksel yang telah terbentuk, terlebih dahulu ditentukan tipenya sebelum digunakan untuk penyisipan data. Tipe kelompok piksel didapatkan berdasarkan perbandingan jumlah piksel dalam kelompok tersebut dengan jumlah piksel dalam satu blok. Persamaan (6) menunjukkan kondisi yang harus dipenuhi untuk masing-masing tipe kelompok.

$$
\text { tipe }= \begin{cases}\text { smooth, } & \text { jika } \# P G \geq\left(\frac{n}{2}\right) \\ \text { rough, } & \text { jika }\left(\frac{n}{2}\right)>\# P G>4 \\ \text { other }, & \text { jika } 4 \geq \# P G \geq 2\end{cases}
$$

Notasi \#PG adalah jumlah piksel dalam satu kelompok dan $n$ adalah jumlah piksel dalam satu blok. Semakin banyak piksel dalam satu kelompok berarti tingkat kemiripan nilai piksel semakin tinggi. Ini berarti ragam nilai piksel dalam satu blok semakin sedikit yang mencerminkan blok tersebut semakin halus (smooth). Masing-masing kelompok kemudian dipilih piksel yang akan digunakan sebagai piksel prediktor dengan cara berbeda-beda. Contoh hasil penentuan piksel prediktor dapat dilihat

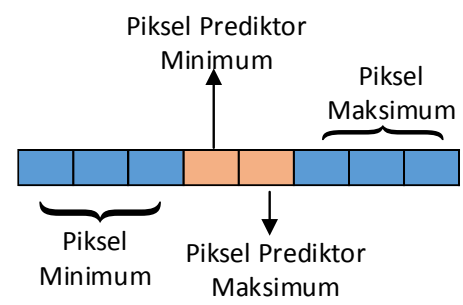

(b)

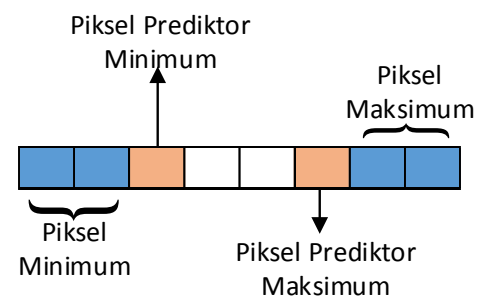

(d)

Gambar 3. Contoh Piksel Prediktor Maksimum dan Minimum, (a) Tipe Smooth Jumlah Piksel Ganjil, (b) Tipe Smooth Jumlah Piksel Genap, (c) Tipe Rough Jumlah Piksel Ganjil, (d) Tipe Rough Jumlah Piksel Genap 
pada Gambar 3 yang menunjukkan piksel prediktor untuk tipe smooth dan rough.

Langkah selanjutnya adalah menghitung prediksi perubahan nilai yang akan terjadi setelah proses penyisipan dilakukan. Proses ini dapat dilakukan menggunakan persamaan (7).

$d_{\text {max }}=P_{u}-P_{v},\left\{\begin{array}{l}u=\min \left(\sigma(j), \sigma\left(r e f_{\text {max }}\right)\right) \\ v=\max \left(\sigma(j), \sigma\left(r e f_{\text {max }}\right)\right)\end{array}\right.$

dengan $d_{\max }$ adalah prediksi perubahan nilai, $\sigma(j)$ adalah indeks piksel pada sub-kelompok maksimum dan $\sigma\left(r e f_{\max }\right)$ adalah indeks piksel prediktor maksimum. Hasil ini kemudian akan disisipi data (b) menggunakan persamaan (8).

$$
d_{\text {max }}^{\prime}= \begin{cases}d_{\max }+b, & \text { jika } d_{\max }=1, \\ d_{\max }+1, & \text { jika } d_{\max }>1, \\ d_{\max }-b, & \text { jika } d_{\max }=0, \\ d_{\max }-1, & \text { jika } d_{\max }<0\end{cases}
$$

Jika pada persamaan (8) nilai $d_{\text {max }}^{\prime}$ melebihi 1 dan data yang disisipkan adalah $b \in\{10,11\}$, maka dilakukan proses REE menggunakan persamaan (9) dan nilai piksel baru $\left(P^{\prime}{ }_{\sigma(j)}\right)$ didapatkan dengan persamaan (10). Sedangkan persamaan (11) untuk $d_{\text {max }}^{\prime}$ yang tidak mengalami reduksi.

$$
\begin{array}{ll}
d^{\prime \prime} \max _{\text {max }} & \text {,jika }\left|d_{\text {max }}^{\prime}\right|>1 \text { dan } b \in\{10,11\} \\
=\left\{\begin{array}{l}
d^{\prime}{ }_{\text {max }} \bmod 2 \\
d^{\prime}{ }_{\text {max }}
\end{array}\right. & , \text { sebaliknya }
\end{array}
$$

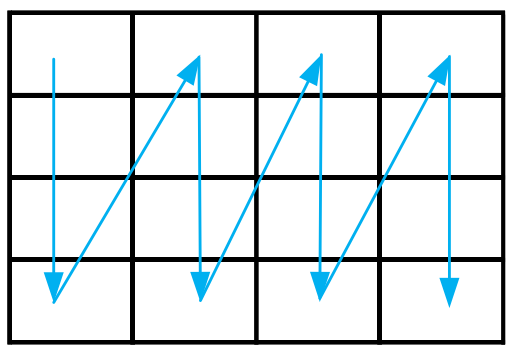

(a)

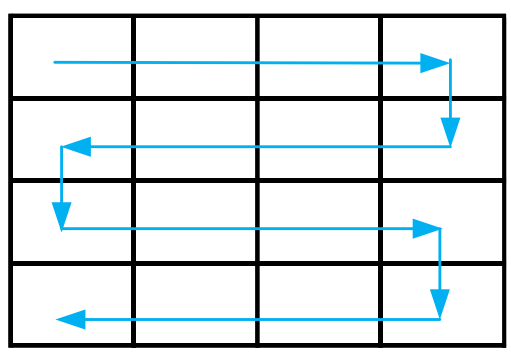

(c)

$$
\begin{aligned}
& P_{\sigma(j)}^{\prime}=P_{\sigma(j)}+\left|d_{\text {max }}^{\prime \prime}\right| \\
& P^{\prime}{ }_{\sigma(j)}=P_{\sigma\left(\text { ref }_{\text {max }}\right)}+\left|d_{\text {max }}^{\prime \prime}\right|
\end{aligned}
$$

$P_{\sigma(j)}$ adalah piksel asli dan $P_{\sigma\left(r e f_{\max }\right)}$ adalah piksel prediktor untuk sub-kelompok maksimum.

Untuk proses ektraksi, Prabowo (2018) menggunakan 2 konsep, yaitu konsep untuk piksel yang mengalami REE dan piksel tanpa REE. Perlu diketahui pula, proses penyisipan dan ekstraksi data ini juga diterapkan dalam sub-kelompok minimum. Dengan menggunakan metode ini, Prabowo (2018) dapat meningkatkan kualitas citra stego dengan ratarata $4,257 \mathrm{~dB}$.

\section{METODE USULAN}

Pada penelitian ini, kami mengadopsi proses penyisipan dan ekstraksi data dari (Prabowo, 2018). Berbeda dengan penelitian tersebut, kami mengusulkan beberapa konsep scanning. Proses scanning terjadi pada saat pembentukan kelompok piksel. Ini dilakukan karena masih belum diketahui secara pasti konsep scanning terbaik pada APBG dan REE seperti harus melakukan scanning pada kolom blok terlebih dahulu atau baris blok. Jika pada metode di (Prabowo, 2018), scanning dilakukan secara baris per baris, kami mengusulkan proses scanning yang berbeda, yaitu seperti terlihat pada Gambar 4. Hal ini dilakukan untuk mengetahui mode-mode scanning yang cocok untuk setiap tipe citra.

\subsection{Konsep Scanning Piksel}

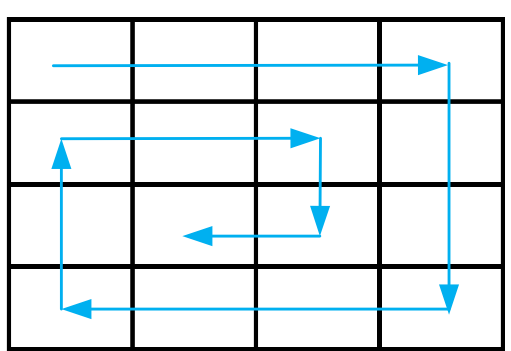

(b)

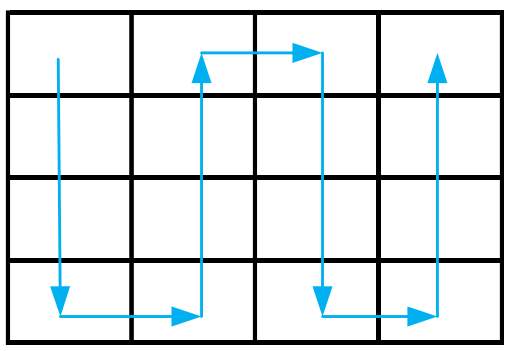

(d) 
Konsep pengurutan piksel pada penelitian ini dibedakan menjadi 4 mode yang dapat dilihat pada Gambar 4. Untuk mode 1, kami melakukan scanning dari kolom-kolom blok terlebih dahulu Gambar 4(a), konsep ini berbeda dengan mode 2 yang akan melakukan scanning secara campuran, yaitu dari baris dan kolom dengan bentuk spiral Gambar 4(b). Konsep lainnya dapat dilihat pada Gambar 4(c) dimana kami akan melakukan scanning secara baris per baris namun untuk baris yang berada pada indeks genap, akan dilakukan scanning secara terbalik dengan baris ganjil. Sedangkan untuk
Gambar 4(d) yang merupakan mode 4 kami menggunakan konsep yang sama seperti mode 3 namun scanning dilakukan dari kolom per kolom.

Contoh untuk masing-masing mode penyisipan dapat dilihat pada Gambar 5, yaitu Gambar 5(a) sebagai hasil dari pembagian citra menjadi blok dan merupakan masukan (inputan) untuk proses pembentukan kelompok piksel. Gambar 5(b)-5(e), menunjukkan hasil pengelompokkan menggunakan konsep scanning piksel mode 1, mode 2, mode 3 dan mode 4. Terlihat pada gambar tersebut, terdapat piksel berwarna biru, merah dan putih. Piksel biru

\begin{tabular}{|l|l|l|l|}
\hline 162 & 162 & 162 & 161 \\
\hline 162 & 162 & 162 & 161 \\
\hline 152 & 155 & 156 & 156 \\
\hline 155 & 155 & 156 & 157 \\
\hline \multicolumn{4}{|c}{ (a) }
\end{tabular}

\begin{tabular}{|c|c|c|c|c|c|c|c|c|c|c|c|c|c|c|c|}
\hline 162 & 162 & 152 & 155 & 162 & 162 & 155 & 155 & 162 & 162 & 156 & 156 & 161 & 161 & 156 & 157 \\
\hline \multicolumn{16}{|c|}{ (b) } \\
\hline 162 & 162 & 162 & 161 & 161 & 156 & 157 & 156 & 155 & 155 & 152 & 162 & 162 & 162 & 156 & 155 \\
\hline \multicolumn{16}{|c|}{ (c) } \\
\hline 162 & 162 & 162 & 161 & 161 & 162 & 162 & 162 & 152 & 155 & 156 & 156 & 157 & 156 & 155 & 155 \\
\hline \multicolumn{16}{|c|}{ (d) } \\
\hline 162 & 162 & 152 & 155 & 155 & 155 & 162 & 162 & 162 & 162 & 156 & 156 & 157 & 156 & 161 & 161 \\
\hline
\end{tabular}

Gambar 5. Contoh hasil pembentukan kelompok piksel. (a) Blok masukan, (b) Hasil mode 1, (c) Hasil mode 2, (d) Hasil mode 3, (e) Hasil mode 4

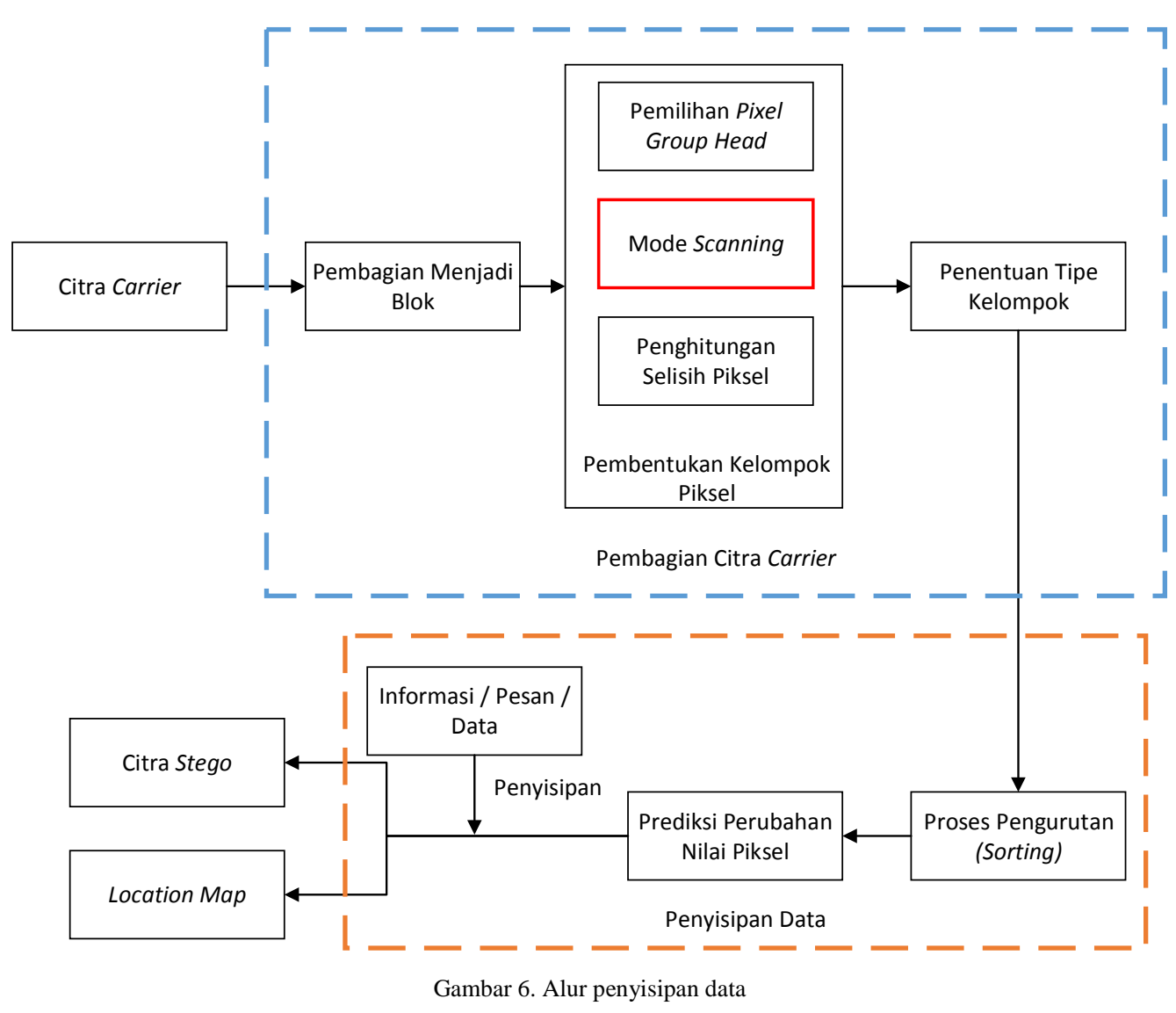


dan merah menandakan bahwa mereka satu kelompok dengan piksel yang berwarna sama. Sedangkan piksel berwarna putih adalah piksel yang tidak dapat digabungkan dalam kelompok piksel dan piksel ini tidak tidak digunakan dalam penyisipan data. Karena hal tersebut, piksel berwarna putih setelah proses penyisipan data selesai, nilainya tidak akan berubah. Dapat dilihat pula, masing-masing mode menghasilkan jumlah kelompok piksel yang berbeda. Mode 1 menghasilkan kelompok piksel berjumlah 7 kelompok piksel. Mode 2 menghasilkan 4 kelompok piksel dan mode 3 serta 4, masingmasing menghasilkan 4 dan 5 kelompok piksel.

\subsection{Penyisipan dan Ekstraksi Data}

Sama dengan metode referensi, proses penyisipan dimulai dari pembagian citra carrier $(I)$ menjadi beberapa blok untuk dibentuk kelompokkelompok piksel. Blok $\{B\}$ yang digunakan merupakan blok yang tidak saling berpotongan (nonoverlapping block), $I=\left\{B_{1}, \ldots, B_{N}\right\}$. Kelompok tersebut kemudian diproses lebih lanjut agar dapat digunakan sebagai piksel pembawa data atau pesan.
Secara garis besar, proses penyisipan data dapat dilihat pada Gambar 6. Berbeda dengan metode referensi, kami menerapkan beberapa mode scanning seperti yang telah dijelaskan pada sub-bab sebelumnya. Penerapan ini terdapat pada proses pembentukan kelompok piksel seperti terlihat pada Gambar 6 dengan warna kotak merah. Setelah terbentuk kelompok-kelompok piksel, penentuan tipe kelompok piksel dilakukan dengan menggunakan persamaan (6).

Hasil penentuan tersebut akan mempengaruhi pemilihan piksel prediktor pada kelompok piksel. Dari pemilihan ini, kita dapat menghitung prediksi perubahan nilai piksel menggunakan persamaan (7) untuk sub-kelompok maksimum. Data atau pesan dapat disisipkan pada nilai prediksi ini menggunakan persamaan (8) yang selanjutnya nilai ini akan ditentukan perlu dilakukan reduksi atau tidak. Persamaan (9) menunjukkan kondisi yang harus dipenuhi jika nilai prediksi yang telah disisipi pesan perlu direduksi. Hasil dari pemrosesan ini akan digunakan untuk menghitung nilai piksel baru menggunakan persamaan (10) atau (11) tergantung pada hasil dari reduksi nilai prediksi.

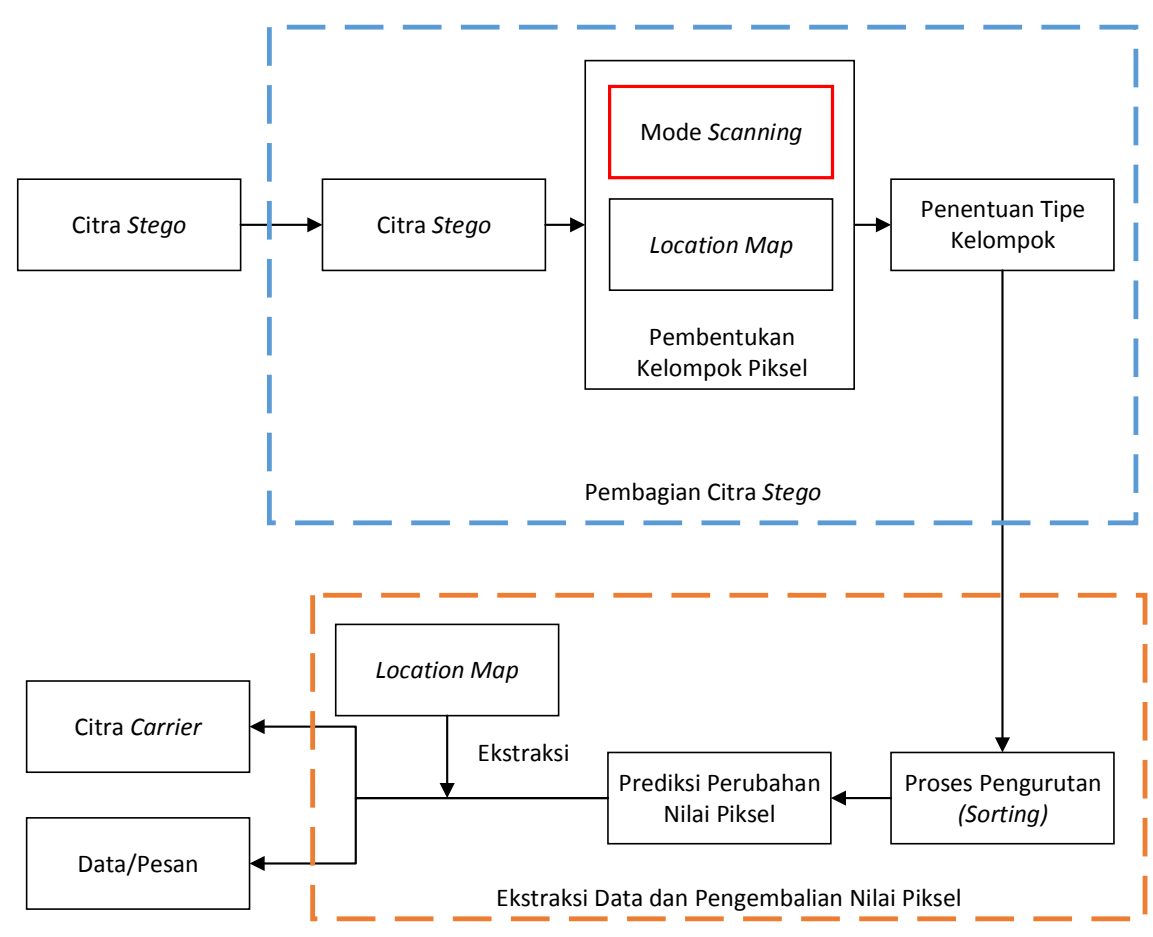

Gambar 7. Proses ekstraksi data atau pesan

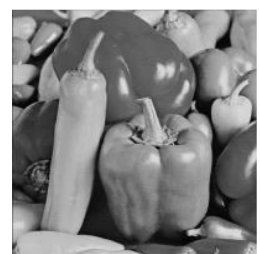

(a)

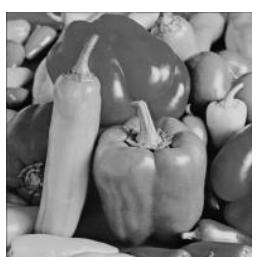

(b)

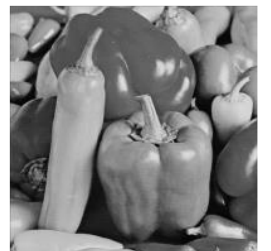

(c)

Gambar 8. Citra 'Pepper'. (a) Carrier, (b) Stego, (c) Hasil ekstraksi 
Untuk proses ekstraksi data, kami menggunakan location map (LM) sebagai pembentuk kelompok piksel dan penentu piksel tersebut mengalami reduksi atau tidak. Keseluruhan proses ekstraksi data secara umum digambarkan pada Gambar 7. Dengan mode scanning yang sama seperti pada proses penyisipan data, kelompok piksel dapat dibentuk dengan jumlah kelompok dan anggota yang sama. Selanjutnya dari proses ini ditentukan tipe kelompoknya dan piksel prediktor untuk kemudian digunakan dalam proses ekstraksi data. Pada penelitian ini, algoritma dan metode ekstraksi data sama seperti pada (Prabowo, 2018).

\section{HASIL DAN PEMBAHASAN}

Pada bagian ini, metode usulan akan dievaluasi dengan membandingkan kualitas citra stego yang dihasilkannya dengan metode referensi, yaitu (Prabowo, 2018), menggunakan nilai Peak Signal to

Tabel 1. Kualitas Citra 'Abdominal'

\begin{tabular}{cccccc}
\hline \multirow{2}{*}{$\begin{array}{c}\text { Data } \\
\text { Kb) }\end{array}$} & \begin{tabular}{c} 
PSNR (dB) \\
\cline { 2 - 6 }
\end{tabular} & $\begin{array}{c}\text { Prabowo, } \\
\text { Mode }\end{array}$ & $\begin{array}{c}\text { Mode } \\
\mathbf{2}\end{array}$ & $\begin{array}{c}\text { Mode } \\
\mathbf{3}\end{array}$ & $\begin{array}{c}\text { Mode } \\
\mathbf{4}\end{array}$ \\
\hline 1 & 78,39 & 78,81 & 78,41 & 78,12 & 78,7 \\
10 & 68,66 & 69,64 & 69,24 & 69,26 & 69,41 \\
20 & 65,76 & 65,8 & 65,45 & 65,52 & 65,49 \\
30 & 64,15 & 63,97 & 63,79 & 63,82 & 63,75 \\
40 & 62,9 & 62,65 & 62,58 & 62,58 & 62,45 \\
50 & 61,92 & 61,63 & 61,58 & 61,65 & 61,5 \\
60 & 61,11 & 60,87 & 60,81 & 60,81 & 60,7 \\
70 & 60,43 & 60,16 & 60,2 & 60,23 & 60,12 \\
80 & 59,85 & 59,63 & 59,66 & 59,7 & 59,52 \\
90 & 59,37 & 59,18 & 59,19 & 59,17 & 59,04 \\
100 & 58,89 & 59,21 & 59,17 & 59,32 & 59,1 \\
\hline
\end{tabular}

Tabel 3. Kualitas Citra 'Chest'

\begin{tabular}{cccccc}
\hline \multirow{2}{*}{$\begin{array}{c}\text { Data } \\
\text { Kb) }\end{array}$} & \multicolumn{5}{c}{ PSNR (dB) } \\
\cline { 2 - 6 } & $\begin{array}{c}\text { Prabowo, } \\
\mathbf{2 0 1 8})\end{array}$ & Mode & Mode & Mode & Mode \\
\hline 1 & 77,62 & 77,53 & 77,54 & 77,75 & 77,43 \\
10 & 68,22 & 68,49 & 68,57 & 68,67 & 68,43 \\
20 & 65,58 & 65,72 & 65,43 & 65,54 & 65,3 \\
30 & 64,11 & 64,28 & 63,98 & 64,12 & 63,89 \\
40 & 62,85 & 63,11 & 62,76 & 62,93 & 62,69 \\
50 & 61,87 & 62,17 & 61,81 & 61,93 & 61,75 \\
60 & 61,16 & 61,44 & 61,04 & 61,16 & 60,93 \\
70 & 60,54 & 60,77 & 60,5 & 60,59 & 60,34 \\
80 & 59,94 & 60,17 & 59,93 & 60,02 & 59,73 \\
90 & 59,39 & 59,64 & 59,38 & 59,44 & 59,23 \\
100 & 58,97 & 59,44 & 59,31 & 59,48 & 59,15 \\
\hline
\end{tabular}

Noise Ratio (PSNR). Penerapan metode usulan menggunakan citra dengan skala abu-abu (grayscale) berukuran $512 \times 512$. Citra ini kami kelompokan menjadi 2, yaitu grayscale image (Baboon, Lena, Boat, Elaine, dan Pepper) dan medical image (Abdominal, Chest, Head, Hand dan Leg). Masing-masing kelompok citra tersebut diunduh dari (USC-SIPI, 1977) dan (System Partners Healthcare Inc., 2002). Data atau pesan yang kami gunakan dalam penerapan ini merupakan data berbentuk biner yang dibentuk menggunakan fungsi rand() dari Matlab. Contoh citra untuk evalusi dapat dilihat pada Gambar 8 yang menunjukkan citra 'Pepper' sebelum penyisipan data, setelah penyisipan data dan setelah ekstraksi data menggunakan mode scanning 2. Dari ketiga citra tersebut, kita dapat melihat bahwa sulit untuk menemukan perbedaannya secara langsung. Hal ini menunjukkan bahwa mode scanning yang kami usulkan tidak mempengaruhi sifat reversible dari

Tabel 2. Kualitas Citra 'Baboon'

\begin{tabular}{|c|c|c|c|c|c|}
\hline \multirow{2}{*}{$\begin{array}{l}\text { Data } \\
\text { (Kb) }\end{array}$} & \multicolumn{5}{|c|}{ PSNR (dB) } \\
\hline & $\begin{array}{c}\text { (Prabowo, } \\
\text { 2018) } \\
\end{array}$ & $\begin{array}{c}\text { Mode } \\
1 \\
\end{array}$ & $\begin{array}{c}\text { Mode } \\
2 \\
\end{array}$ & $\begin{array}{c}\text { Mode } \\
\mathbf{3} \\
\end{array}$ & $\begin{array}{c}\text { Mode } \\
4 \\
\end{array}$ \\
\hline 1 & 75,56 & 75,44 & 75,35 & 75,32 & 75,77 \\
\hline 10 & 65,55 & 68,11 & 67,24 & 67,22 & 67,49 \\
\hline 20 & 62,55 & 62,59 & 62,52 & 62,49 & 62,6 \\
\hline 30 & - & - & - & - & - \\
\hline 40 & - & - & - & - & - \\
\hline 50 & - & - & - & - & - \\
\hline 60 & - & - & - & - & - \\
\hline 70 & - & - & - & - & - \\
\hline 80 & - & - & - & - & - \\
\hline 90 & - & - & - & - & - \\
\hline 100 & - & - & - & - & - \\
\hline
\end{tabular}

Tabel 4. Kualitas Citra 'Boat'

\begin{tabular}{|c|c|c|c|c|c|}
\hline \multirow{2}{*}{$\begin{array}{l}\text { Data } \\
(\mathbf{K b})\end{array}$} & \multicolumn{5}{|c|}{ PSNR (dB) } \\
\hline & $\begin{array}{c}\text { (Prabowo, } \\
\text { 2018) }\end{array}$ & $\begin{array}{c}\text { Mode } \\
1 \\
\end{array}$ & $\begin{array}{c}\text { Mode } \\
2 \\
\end{array}$ & $\begin{array}{c}\text { Mode } \\
\mathbf{3} \\
\end{array}$ & $\begin{array}{c}\text { Mode } \\
4 \\
\end{array}$ \\
\hline 1 & 76,04 & 75,94 & 76,14 & 76,15 & 75,87 \\
\hline 10 & 65,79 & 66,5 & 66,49 & 66,51 & 66,51 \\
\hline 20 & 62,8 & 62,78 & 62,81 & 62,78 & 62,79 \\
\hline 30 & 61,1 & 61,01 & 61,06 & 61,01 & 61 \\
\hline 40 & 59,87 & 59,8 & 59,87 & 59,82 & 59,79 \\
\hline 50 & 58,87 & 58,86 & 58,87 & 58,86 & 58,86 \\
\hline 60 & - & - & - & - & - \\
\hline 70 & - & - & - & - & - \\
\hline 80 & - & - & - & - & - \\
\hline 90 & - & - & - & - & - \\
\hline 100 & - & - & - & - & - \\
\hline
\end{tabular}


Tabel 5. Kualitas Citra 'Hand'

\begin{tabular}{cccccc}
\hline \multirow{2}{*}{$\begin{array}{c}\text { Data } \\
(\text { Kb })\end{array}$} & \multicolumn{5}{c}{ PSNR (dB) } \\
\cline { 2 - 6 } & $\begin{array}{c}\text { Prabowo, } \\
\mathbf{2 0 1 8})\end{array}$ & $\begin{array}{c}\text { Mode } \\
\mathbf{1}\end{array}$ & $\begin{array}{c}\text { Mode } \\
\mathbf{2}\end{array}$ & $\begin{array}{c}\text { Mode } \\
\mathbf{3}\end{array}$ & $\begin{array}{c}\text { Mode } \\
\mathbf{4}\end{array}$ \\
\hline 1 & 76,99 & 74,57 & 76,08 & 76,65 & 76,38 \\
10 & 67,54 & 67,47 & 67 & 67,64 & 67,17 \\
20 & 64,64 & 64,29 & 63,95 & 64,47 & 64,06 \\
30 & 63,08 & 62,75 & 62,52 & 62,92 & 62,44 \\
40 & 61,82 & 61,59 & 61,38 & 61,74 & 61,32 \\
50 & 60,88 & 60,63 & 60,53 & 60,83 & 60,43 \\
60 & 60,14 & 59,91 & 59,81 & 60,08 & 59,69 \\
70 & 59,48 & 59,23 & 59,2 & 59,44 & 59,05 \\
80 & 58,94 & 58,7 & 58,68 & 58,92 & 58,55 \\
90 & 58,36 & 58,12 & 58,17 & 58,37 & 58,04 \\
100 & 57,93 & 57,83 & 57,81 & 58,01 & 57,67 \\
\hline
\end{tabular}

Tabel 7. Kualitas Citra 'Head'

\begin{tabular}{cccccc}
\hline \multirow{2}{*}{$\begin{array}{c}\text { Data } \\
(\mathbf{K b})\end{array}$} & \multicolumn{5}{c}{ PSNR (dB) } \\
\cline { 2 - 6 } & $\begin{array}{c}\text { (Prabowo, } \\
\mathbf{2 0 1 8})\end{array}$ & $\begin{array}{c}\text { Mode } \\
\mathbf{1}\end{array}$ & $\begin{array}{c}\text { Mode } \\
\mathbf{2}\end{array}$ & $\begin{array}{c}\text { Mode } \\
\mathbf{3}\end{array}$ & $\begin{array}{c}\text { Mode } \\
\mathbf{4}\end{array}$ \\
\hline 1 & 79,37 & 78,79 & 79,11 & 78,99 & 79,46 \\
10 & 69,46 & 69,63 & 69,63 & 69,47 & 69,66 \\
20 & 66,11 & 66,34 & 66,15 & 66,07 & 66,28 \\
30 & 64,35 & 64,54 & 64,29 & 64,27 & 64,32 \\
40 & 63,04 & 63,02 & 62,86 & 62,92 & 62,94 \\
50 & 62 & 61,97 & 61,88 & 61,91 & 61,87 \\
60 & 61,23 & 61,08 & 61,03 & 61 & 60,98 \\
70 & 60,5 & 60,37 & 60,36 & 60,35 & 60,32 \\
80 & 59,94 & 59,84 & 59,78 & 59,79 & 59,72 \\
90 & 59,51 & 59,37 & 59,31 & 59,32 & 59,26 \\
100 & - & - & - & - & - \\
\hline
\end{tabular}

metode data hiding yang digunakan.

Perihal kualitas citra stego untuk konsep yang kami usulkan, kami melakukan uji coba dengan menyisipkan data dengan ukuran yang berbeda-beda yaitu $1 \mathrm{~Kb}-100 \mathrm{~Kb}$. Hasil dari uji coba tersebut ditunjukkan pada Tabel 1-10 untuk masing-masing gambar. Uji coba ini menggunakan blok berukuran $4 \times 4$ dengan $E L=1$.

Dapat kita lihat, masing-masing citra memiliki nilai PSNR terbaik pada mode scanning dan ukuran data yang berbeda-beda. Misal pada citra 'Abdominal' dengan ukuran data $10 \mathrm{~Kb}$ mendapatkan kualitas terbaik $(69,64$ dB) jika menerapkan mode 1 untuk proses scanning. Namun hal ini akan berubah seperti yang terlihat ketika menyisipkan data berukuran $100 \mathrm{~Kb}$, kualitas terbaik tercipta saat mode 3 untuk scanning diterapkan $(59,32 \mathrm{~dB})$. Kasus yang sama juga terjadi pada kelompok grayscale image. Citra 'Elaine' memiliki kualitas terbaik dengan ukuran data yang disisipkan
Table 6. Kualitas Citra 'Elaine'

\begin{tabular}{|c|c|c|c|c|c|}
\hline \multirow{2}{*}{$\begin{array}{l}\text { Data } \\
(\mathbf{K b})\end{array}$} & \multicolumn{5}{|c|}{$\operatorname{PSNR}(\mathrm{dB})$} \\
\hline & $\begin{array}{c}\text { (Prabowo, } \\
\text { 2018) }\end{array}$ & $\begin{array}{c}\text { Mode } \\
1 \\
\end{array}$ & $\begin{array}{c}\text { Mode } \\
2 \\
\end{array}$ & $\begin{array}{c}\text { Mode } \\
\mathbf{3} \\
\end{array}$ & $\begin{array}{c}\text { Mode } \\
4 \\
\end{array}$ \\
\hline 1 & 77,49 & 77,56 & 77,37 & 77,39 & 77,6 \\
\hline 10 & 66,43 & 66,91 & 66,84 & 66,86 & 66,94 \\
\hline 20 & 63,09 & 63,12 & 63,14 & 63,1 & 63,14 \\
\hline 30 & 61,23 & 61,2 & 61,26 & 61,2 & 61,2 \\
\hline 40 & 59,9 & 59,86 & 59,89 & 59,86 & 59,89 \\
\hline 50 & 58,9 & 58,86 & 58,89 & 58,9 & 58,92 \\
\hline 60 & - & - & - & - & - \\
\hline 70 & - & - & - & - & - \\
\hline 80 & - & - & - & - & - \\
\hline 90 & - & - & - & - & - \\
\hline 100 & - & - & - & - & - \\
\hline
\end{tabular}

Table 8. Kualitas Citra 'Lena'

\begin{tabular}{|c|c|c|c|c|c|}
\hline \multirow{2}{*}{$\begin{array}{l}\text { Data } \\
(\mathbf{K b})\end{array}$} & \multicolumn{5}{|c|}{ PSNR (dB) } \\
\hline & $\begin{array}{c}\text { (Prabowo, } \\
\text { 2018) } \\
\end{array}$ & $\begin{array}{c}\text { Mode } \\
1 \\
\end{array}$ & $\begin{array}{c}\text { Mode } \\
2 \\
\end{array}$ & $\begin{array}{c}\text { Mode } \\
\mathbf{3} \\
\end{array}$ & $\begin{array}{c}\text { Mode } \\
4 \\
\end{array}$ \\
\hline 1 & 76,15 & 78,15 & 77,56 & 77,83 & 78,15 \\
\hline 10 & 65,98 & 66,83 & 66,64 & 66,59 & 66,89 \\
\hline 20 & 62,98 & 63,18 & 63,17 & 63,11 & 63,23 \\
\hline 30 & 61,21 & 61,44 & 61,39 & 61,37 & 61,39 \\
\hline 40 & 59,96 & 60,07 & 60,05 & 60,03 & 60,07 \\
\hline 50 & 58,99 & 59,06 & 59,04 & 59,02 & 59,06 \\
\hline 60 & 58,19 & 58,24 & 58,28 & 58,22 & 58,26 \\
\hline 70 & 57,5 & 57,6 & 57,61 & 57,59 & 57,62 \\
\hline 80 & - & - & - & - & - \\
\hline 90 & - & - & - & - & - \\
\hline 100 & - & - & - & - & - \\
\hline
\end{tabular}

sebesar $10 \mathrm{~Kb}$ jika menerapkan mode $4(66,94 \mathrm{~dB})$. Kondisi tersebut berubah saat menyisipkan data sebesar $30 \mathrm{~Kb}$, yaitu menggunakan mode 3 untuk mendapatkan kualitas terbaik $(61,26 \mathrm{~dB})$.

Perubahan-perubahan ini disebabkan oleh jumlah shifted pixel yang terbentuk ketika proses penyisipan data telah selesai. Keadaan ini dapat dilihat pada Tabel 11 yang menunjukkan jumlah shifted pixel yang terbentuk pada citra 'Elaine'. Dengan ukuran data $10 \mathrm{~Kb}$, citra 'Elaine' memiliki 884 shifted pixel pada mode 4 yang merupakan mode dengan kualitas citra stego terbaik. Hal ini 450 lebih sedikit dibandingkan dengan mode 1 yang memiliki 1334 shifted pixel dengan kualitas citra yang didapatkan adalah $66,43 \mathrm{~dB}$. Sehingga semakin tinggi jumlah shifted pixel yang terbentuk, maka kualitas citra stego juga akan semakin menurun. Kondisi ini sesuai dengan pernyataan yang disampaikan oleh Li dkk (2013) bahwa jumlah 
Tabel 9. Kualitas Citra 'Leg'

\begin{tabular}{cccccc}
\hline \multirow{2}{*}{$\begin{array}{c}\text { Data } \\
\text { Kb) }\end{array}$} & $\begin{array}{c}\text { Prabowo, } \\
\text { 2018) }\end{array}$ & $\begin{array}{c}\text { Mode } \\
\mathbf{1}\end{array}$ & Mode 2 & Mode 3 & Mode 4 \\
\hline 1 & 77,97 & 78,18 & 77,65 & 78,07 & 76,96 \\
10 & 67,09 & 67,7 & 67,37 & 67,46 & 67,35 \\
20 & 64,27 & 64,72 & 64,17 & 64,29 & 64,21 \\
30 & 62,69 & 63,1 & 62,55 & 62,74 & 62,61 \\
40 & 61,43 & 61,83 & 61,29 & 61,44 & 61,32 \\
50 & 60,48 & 60,84 & 60,39 & 60,53 & 60,37 \\
60 & 59,71 & 60,07 & 59,6 & 59,78 & 59,64 \\
70 & 59,03 & 59,37 & 58,99 & 59,11 & 59,04 \\
80 & 58,48 & 58,81 & 58,44 & 58,56 & 58,49 \\
90 & 57,96 & 58,3 & 57,92 & 58,04 & 57,97 \\
100 & 57,53 & 57,9 & 57,53 & 57,73 & 57,63 \\
\hline
\end{tabular}

Tabel 11. Shifted Pixel pada Citra 'Elaine'

\begin{tabular}{cccccc}
\hline \multirow{2}{*}{$\begin{array}{c}\text { Data } \\
\text { Kb) }\end{array}$} & $\begin{array}{c}\text { Jumlah Shifted Pixel } \\
\text { (P18) }\end{array}$ & $\mathbf{1}$ & $\mathbf{2}$ & $\mathbf{3}$ & $\mathbf{4}$ \\
\hline 1 & 59 & 70 & 73 & 71 & 63 \\
10 & 1334 & 895 & 976 & 969 & 884 \\
20 & 3307 & 3356 & 3270 & 3377 & 3298 \\
30 & 5428 & 5516 & 5325 & 5493 & 5450 \\
40 & 7445 & 7585 & 7396 & 7533 & 7460 \\
50 & 9424 & 9596 & 9464 & 9511 & 9365 \\
60 & - & - & - & - & - \\
70 & - & - & - & - & - \\
80 & - & - & - & - & - \\
90 & - & - & - & - & - \\
100 & - & - & - & - & - \\
\hline
\end{tabular}

shifted pixel akan mempengaruhi baik buruknya kualitas citra stego.

Kami juga melakukan uji coba untuk mengetahui perubahan kualitas citra stego jika embedding level atau threshold (EL) diubah. Hasil dari pengujian ini dapat dilihat pada Tabel 12 yang menunjukkan kualitas citra stego dari citra 'Elaine' dengan $\mathrm{EL}=1$ hingga $\mathrm{EL}=5$ dan data $=10 \mathrm{~Kb}$ untuk masing-masing mode scanning. Kita dapat melihat kualitas citra stego mengalami penurunan untuk semua mode scanning. Hal ini karena semakin tinggi nilai EL, maka semakin banyak jumlah shifted pixel yang dihasilkan seperti terlihat pada Tabel 13 . Ini memberikan pengaruh negatif pada kualitas citra stego jika jumlah shifted pixel terus bertambah.

Hal lain yang dapat dilihat pada Tabel 12 adalah perbandingan kualitas citra stego dengan metode usulan yang dibandingkan dengan metode di
Table 10. Kualitas Citra 'Pepper'

\begin{tabular}{|c|c|c|c|c|c|}
\hline \multirow{2}{*}{$\begin{array}{l}\text { Data } \\
\text { (Kb) }\end{array}$} & \multicolumn{5}{|c|}{ PSNR (dB) } \\
\hline & $\begin{array}{c}\text { (Prabowo, } \\
\text { 2018) }\end{array}$ & $\begin{array}{c}\text { Mode } \\
1\end{array}$ & $\begin{array}{c}\text { Mode } \\
2\end{array}$ & $\begin{array}{c}\text { Mode } \\
3\end{array}$ & $\begin{array}{c}\text { Mode } \\
4\end{array}$ \\
\hline 1 & 75,82 & 75,92 & 76,28 & 75,82 & 75,94 \\
\hline 10 & 65,84 & 66,61 & 66,54 & 66,51 & 66,5 \\
\hline 20 & 62,82 & 62,91 & 62,9 & 62,9 & 62,85 \\
\hline 30 & 61,05 & 61,19 & 61,15 & 61,15 & 61,14 \\
\hline 40 & 59,79 & 59,86 & 59,83 & 59,86 & 59,87 \\
\hline 50 & 58,8 & 58,85 & 58,84 & 58,83 & 58,84 \\
\hline 60 & 58,04 & 58,04 & 58,03 & 58,04 & 58,06 \\
\hline 70 & - & - & - & - & - \\
\hline 80 & - & - & - & - & - \\
\hline 90 & - & - & - & - & - \\
\hline 100 & - & - & - & - & - \\
\hline
\end{tabular}

Tabel 12. Perubahan Embedding Level/Threshold pada Citra 'Elaine'

\begin{tabular}{cccccc}
\hline \multirow{5}{*}{ EL } & \multicolumn{5}{c}{ PSNR (dB) } \\
\cline { 2 - 6 } & $\begin{array}{c}\text { (Prabowo } \\
\text { \& Ahmad, } \\
\text { 2018) }\end{array}$ & Mode 1 & Mode 2 & Mode 3 & Mode 4 \\
\hline 1 & 61,83 & 66,91 & 66,84 & 66,86 & 66,94 \\
2 & 60,09 & 64,42 & 64,48 & 64,43 & 64.44 \\
3 & 58,11 & 63,44 & 63,36 & 63,37 & 63.45 \\
4 & 56,83 & 62,72 & 62,65 & 62,68 & 62.74 \\
5 & 55,21 & 62,12 & 62,06 & 62,16 & 62.22 \\
\hline
\end{tabular}

Tabel 13. Shifted Pixel Citra 'Elaine' dengan EL yang Berbeda

\begin{tabular}{ccccc}
\hline EL & Mode 1 & Mode 2 & Mode 3 & Mode 4 \\
\hline 1 & 895 & 976 & 969 & 884 \\
2 & 3605 & 3550 & 3564 & 3567 \\
3 & 5189 & 5339 & 5298 & 5191 \\
4 & 6545 & 6740 & 6653 & 6548 \\
5 & 7951 & 8083 & 7816 & 7692 \\
\hline
\end{tabular}

(Prabowo \& Ahmad, 2018). Secara keseluruhan kualitas citra stego dari metode yang kami usulkan pada penelitian ini memiliki kualitas citra stego lebih baik dibandingkan dengan hasil dari (Prabowo \& Ahmad, 2018). Kondisi ini terjadi karena pada metode tersebut tidak menggunakan pembagian blok, sehingga tidak dapat menentukan cara scanning yang tepat untuk mendapatkan kualitas citra stego yang terbaik.

\section{KESIMPULAN}

Pada penelitian ini, beberapa mode scanning saat pembentukan kelompok piksel diusulkan untuk 
mendapatkan metode scanning terbaik yang dapat menciptakan citra stego dengan kualitas tinggi. Metode ini dibedakan menjadi 4 mode dengan masing-masing melakukan scanning pertama kali pada baris atau kolom dari blok yang terbentuk. Hasil uji coba menunjukkan bahwa masing-masing kelompok citra mendapatkan kualitas terbaiknya pada mode scanning yang berbeda-beda. Misalnya pada citra 'Elaine', kualitas citra stego terbaik $(66,94$ $\mathrm{dB}$ ) didapatkan dari mode 4 untuk ukuran pesan 10 $\mathrm{Kb}$. Sedangkan untuk citra 'Hand' berasal dari mode 3 yaitu 67,64 dB. Keadaan ini terjadi karena pada masing-masing mode menghasilkan jumlah shifted pixel yang berbeda pula. Mode scanning dengan shifted pixel paling sedikit akan menghasilkan kualitas citra stego terbaik. Sebaliknya, mode scanning dengan jumlah shifted pixel yang tinggi akan menciptakan citra stego dengan kualitas yang buruk.

\section{DAFTAR PUSTAKA}

Al-HOOTI, M., DJANALI, S. \& AHMAD, T., 2016. Audio Data Hiding Based on Sample Value Modification Using Modulus Function. Journal of Information Processing Systems, 12(3), pp. 525-537.

ANDRA, M. B., AHMAD, T. \& USAGAWA, T., 2017. Medical Record protection with improved GRDE data hiding method on audio files. Engineering Letters, 25(2), pp. 112-124.

ARYA, M. S., RANI, M. \& BEDI, C. S., 2016. Improved Capacity Image Steganography Algorithm using 16-Pixel Differencing with n-bit LSB Substitution for RGB Images. International Journal of Electrical and Computer Engineering, 6(6), pp. 27352741.

CHEN, N., SU, C., SHIH, C. \& CHEN, Y., 2016. Reversible Watermarking for Medical Image using Histogram Shifting with Location Map Reduction. Taipei, s.n., pp. 792-797.

CISCO, 2016. Cisco Global Cloud Index: Forecast and Methodology, 2015-2020, s.1.: Cisco Public.

GUI, X., LI, X. \& YANG, B., 2012. A Novel Integer Transform for Efficient Reversible Watermarking. Tsukuba, s.n., p. 947-950.

HOLIL, M. \& AHMAD, T., 2014. Peningkatan Performa Metode Steganografi Berbasis Difference Expansion Menggunakan Reduksi Selisih. Jurnal Ilmiah Teknologi Informasi, 12(2), pp. 9-17.

HOLIL, M. \& AHMAD, T., 2015. Secret Data Hiding by Optimizing General Smoothness Difference Expansion-Based Method. Journal of Theoretical and Applied Information Technology, 72(2), pp. 155163.
IOAN-CATALIN, D. \& COLTUC, D., 2014. LocalPrediction-Based Difference Expansion Reversible Watermarking. IEEE Transaction on Image Processing, 23(4), pp. 1779-1790.

KURNIAWAN, Y. \& AHMAD, T., 2016. Pengembangan Metode Pengaman Berkas Memanfaatkan Pewarnaan Graf. Jurnal Ilmiah Teknologi Informasi, 14(2), pp. 190197.

LIU, M. et al., 2012. Reducing Location Map in Prediction-based Difference Expansion for Reversible Image Data Embedding. Signal Processing, 92(3), pp. 819-828.

LI, X., LI, J., LI, B. \& YANG, B., 2013. HighFidelity Reversible Data Hiding Scheme Based on Pixel-Value-Ordering and Prediction-Error-Expansion. Signal Processing, 93(1), pp. 198-205.

MARWAN, S., SHAWISH, A. \& NAGATY, K., 2016. DNA-based Cryptographic Methods for Data Hiding in DNA Media. Biosystems, Volume 150, pp. 110-118.

NI, Z., SHI, Y.-Q., ANSARI, N. \& Su, W., 2006. Reversible Data Hiding. IEEE Transaction on Circuits and Systems for Video Technology, 16(3), pp. 354-362.

OU, B., LI, X. \& WANG, J., 2016. High-Fidelity Reversible Data Hiding Based on PixelValue-Ordering and Pairwise PredictionError Expansion. Journal of Visual Communicatin and Image Representation, Volume 39, pp. 12-23.

OU, B. et al., 2013. Pairwise Prediction-Error Expansion for Efficient Reversible Data Hiding. IEEE Transactions on Image Processing, 22(12), pp. 5010-5021.

PENG, F., LI, X. \& YANG, B., 2012. Adaptiave Reversible Data HIding Scheme Based on Integer Transform. Signal Processing, 92(1), pp. 54-62.

PENG, F., LI, X. \& YANG, B., 2014. Improved PVO-based Reversible Data Hiding. Digital Signal Processing, Volume 25, pp. 255256.

PRABOWO, H. E., 2018. Peningkatan Kinerja Prediction Error Expansion dalam Data Hiding dengan Mereduksi Error Expansion dan Mengelompokkan Nilai Piksel Secara Adaptif, Surabaya: Institut Teknologi Sepuluh Nopember.

PRABOWO, H. E. \& AHMAD, T., 2018. Adaptive Pixel Value Grouping for Protecting Secret Data in Public Computer Networks. Journal of Communications, 13(6).

System Partners Healthcare Inc., 2002. Partners Infectious Disaese Images eMicrobes Digital Library. [Online] Available at: http://www.idimages.org/ [Diakses 1 November 2017]. 
196 Jurnal Teknologi Informasi dan Ilmu Komputer (JTIIK), Vol. 5, No. 2, Mei 2018, hlm. 185-196

TIAN, J., 2003. Reversible Data Embedding Using A Difference Expansion. IEEE Transactions on Circuits and Systems for Video Technology, 13(8), pp. 890-896.

USC-SIPI, 1977. The USC-SIPI Image Database. [Online]

Available at: http://sipi.usc.edu/database [Diakses 26 April 2017].

WENG, S., PAN, J.-S. \& LI, L., 2016. Reversible data hiding based on an adaptive pixelembedding strategy and two-layer embedding. Information Sciences, Volume 369, pp. 144-159.

WU, M., 2002. Part-I Fundamental Issues and Solutions. IEEE Transaction on Image Processing, Volume 12, pp. 685-695. 